\title{
RADIOCARBON DATING OF PEAT PROFILE WITH METALLURGY INDUSTRY EVIDENCE
}

\author{
KONRAD TUDYKA and ANNA PAZDUR \\ Department of Radioisotopes (GADAM Centre of Excellence), Institute of Physics, \\ Silesian University of Technology, Krzywoustego 2, 44-100 Gliwice, Poland
}

Received 19 November 2009

Accepted 1 March 2010

\begin{abstract}
In this work an age model for a peat core from the site near Żyglin, based on ${ }^{14} \mathrm{C}$ is presented. The investigated profile is marked with some possible evidence of early human activity in this region. The earliest metallurgy industry is expected to correspond with charcoal production and the recent increase of metal content in this profile. In this work the Quantulus $1220^{\mathrm{TM}}$ recently purchased was used for ${ }^{14} \mathrm{C}$ dating with liquid scintillation counting (LSC) technique. Therefore results of calibration, tests and verification with use of samples from inter-comparison programs (VIRI, FIRI) are also presented.
\end{abstract}

Keywords: ${ }^{14} \mathrm{C}$ dating, LSC, peat, Poland, Żyglin

\section{INTRODUCTION}

In the Upper Silesia (the South of Poland) there are a few archaeological sites with evidence of early human activity and therefore they are very valuable in archaeological investigations. Probably one of the most important type are peat-bogs. Growing peat-bogs recorded human activity as change of $\mathrm{Pb}, \mathrm{Cu}, \mathrm{Zn}$ and other elements introduced by metallurgy industry.

First investigations showed that metallurgy industry had a large impact from $9^{\text {th }}$ century (AD) until the Second World War. Those investigations were carried out and described by Chróst et al. (2007 and 2008). It was shown that a large amount of charcoal and metals is deposited in peat. This is known to be typical for early metallurgy based on ores of $\mathrm{Fe}_{2} \mathrm{O}_{3}$ and $\mathrm{Fe}_{2} \mathrm{O}_{3} \cdot \mathrm{nH}_{2} \mathrm{O}$ (Godfrey-Smith and Casey, 2003; Rapp, 2009). Moreover, charcoal, Pb, $\mathrm{Zn}, \mathrm{Cu}$ as well as some other metals are very often considered as immobile in peat (Vile et al., 1999, Ali et al., 2008). This ensures suitability of profiling $\mathrm{Pb}, \mathrm{Zn}$ and $\mathrm{Cu}$ in peat profiles to trace metallurgical activity. Investigations were made by Laboratory for Ecological Research, Measurement and Expertise "EKOPOMIAR" Leszek Chróst from Gliwice and Environmental Protection Section of Society of Friends of Tarnogórska Land from Tarnowskie Góry. Chemical analyses of concentration of

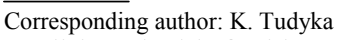
e-mail: konrad.tudyka@polsl.com

ISSN 1897-1695 (online), 1733-8387 (print) (C) 2010 GADAM Centre, Institute of Physics, Silesian University of Technology.

All rights reserved. metals were made by the Center of Environmental Control and Survey from Katowice.

One of investigated peat areas (Fig. 1) near Żyglin was marked with the very large amount of charcoal, even in comparison with other peat profiles from this area. The first radiocarbon dating showed that peat core covers the Iron and Bronze Age.

Independent investigations were started by unit from the Center of Environmental Control and Survey (Greger and Składowski, 2009). The Gliwice Radiocarbon Laboratory began its own project of creating the age-depth model which will bond all the events to absolute time scale.

\section{2. ŻYGLIN SITE}

The material was collected near Żyglin (Fig. 1). The coordinates of the taken core are N 50 $28^{\prime} 56.20^{\prime \prime}$, E 18 59'12.19', $249 \mathrm{~m}$ AMSL. The fen has a triangular shape and was devastated by drainage twice: in the interwar period and in the 1980s. The peat spans over the area of 2 ha and is situated near the drainage basin of the Brynica river. Thanks to $20 \mathrm{~cm}$ of sand layer covering the surface, the fen was preserved for a long period of time. Until 2009, 8 profiles were investigated from this fen. Profiles marked by numbers 2 and 3, dated in this paper by radiocarbon method, come from the same part where the largest thickness of fen-bed was found. The previous dating of fen bedrock layer in profile 1, with the use of 


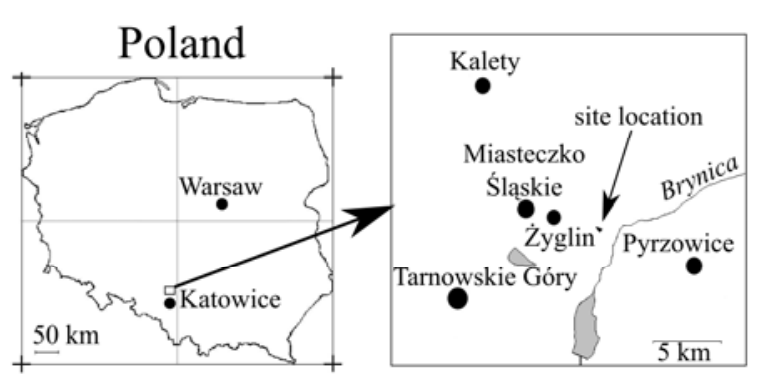

Fig. 1. Location of peat-bog near Żyglin.

conventional ${ }^{14} \mathrm{C}$ method suggested continuity of peat growth in the last 12,000 years.

In the upper part of the core a large amount of charcoal was found. Four samples of carbonized wood from this fen were dated in Poznan Radiocarbon Laboratory with the use of AMS method (financed by Municipal Office of Miasteczko Śląskie and Zinc Works "Miasteczko Śląskie"). Final conventional age results were calibrated using OxCal v4.1.3 (Bronk Ramsey, 2009) and IntCal04 Northern Hemisphere calibration curve (Reimer et al., 2004).

It was showed that charcoal pollution process took place from around $2500 \mathrm{BC}$ (Table 1). A hypothesis was put forward, that such a long period of charcoal production was connected with igneously gentrified ochre (hematite), which occurs in Żyglin region and in subsequent period with siderurgy and for smaller scale with metallurgy of lead and silver. Copper content measurements show unexpected triple increase of this metal on the depth from 61 to $62 \mathrm{~cm}$, compared to other parts of the core (Greger and Skałdowski, 2009). The large amount of charcoal in this profile is found to the depth of $64 \mathrm{~cm}$. In summary, it can be said that results obtained from measurements done so far suggest the existence of metallurgy industry (copper, lead, silver and iron) in the last 4000 years. This roughly matches know human settlement and activities in this part of Europe (Bellwood, 2004; Cavalli-Sforza et al., 1994). Initial chemical analysis also showed, that in the earliest period ochre (hematite) was igneously gentrified.

\section{3. ${ }^{14}$ C DATING}

\section{Sampling}

The peat core was taken near the drainage ditch after removing approximately $1.5 \mathrm{~m}$ of peat up to a place not affected by human activity. The total length of the core was $130 \mathrm{~cm}$. The uppermost $20 \mathrm{~cm}$-section of the core was composed mainly of the sand, the remaining $110 \mathrm{~cm}$ was composed of peat. The core was cut into slices $1 \mathrm{~cm}$ each in the upper part $(20-90 \mathrm{~cm})$ and in the lower part $(90-130 \mathrm{~cm})$ each $2.5 \mathrm{~cm}$. In order to avoid enriching material with modern ${ }^{14} \mathrm{C}$ the samples were stored in the dark room in the fridge until further procedures were undertaken.

\section{Chemical pre-treatment of the samples and conver- sion to benzene}

Samples were treated with the standard procedure Acid-Alkali-Acid (Cook et al., 1998) to remove humic acids, chitin, fungal products, etc. Next, they were pyrolised in a reactor at $650^{\circ} \mathrm{C}$ and lithium carbide was produced at $800^{\circ} \mathrm{C}$. Subsequently, the lithium carbide was flooded with demineralised water to obtain acetylene $\left(\mathrm{C}_{2} \mathrm{H}_{2}\right)$. In the final stage, benzene $\left(\mathrm{C}_{6} \mathrm{H}_{6}\right)$ was obtained by the catalytic trimerization of acetylene on vanadium catalyst. Benzene line was designed and produced by Skripkin from Kiev. More detailed description of vacuum rig for benzene synthesis can be found in Pawlyta et al. (1998). The benzene production samples were stored for over one month to let all ${ }^{222} \mathrm{Rn}$ and daughter isotopes to decay.

\section{Calibration of Quantulus and ${ }^{14} \mathrm{C}$ measurement}

In 2008, the new Quantulus $1220^{\mathrm{TM}}$ was installed in Gliwice Radiocarbon Laboratory. Before using for routine measurements, the new Quantulus $1220^{\mathrm{TM}}$ required calibration and a verification test. We performed calibration according to Pawlyta et al. 1998 for $2 \mathrm{ml}$ geometry samples since we were very confident with our earlier results.

The pulse amplitude comparator allows to reduce the background by rejecting events giving vastly different pulses ratio in two photo multiplier tubes. The PAC level is allowing to adjust such a ratio. As a result of calibration the optimal value of PAC was chosen where following function reaches the minimum value:

$$
O(\mathrm{PAC})=\frac{B(\mathrm{PAC})}{E_{r}^{2}(\mathrm{PAC})},
$$

where: $E_{r}$ - relative counting efficiency, $B$ - background counting rate. $E_{r}$ and $B$ are functions of PAC. In Eq. 3.1, $E_{r}$ in is calculated according to:

$$
E_{r}(\mathrm{PAC})=\frac{S_{0 \mathrm{u} \max }}{S_{0 \mathrm{u}}(\mathrm{PAC})},
$$

where: $S_{0}$ is modern standard counting rate calculated according to Polach and Stuiver (1977), $S_{0 \max }$ responds to the highest counting rate of modern standard and

\begin{tabular}{|c|c|c|c|}
\hline Charcoal sample No. & Conventional age (BP) & Calibrated age range $68.2 \%$ & Calibrated age range $95.4 \%$ \\
\hline & & & $2475-2285 \mathrm{BC}(93.8 \%)$ \\
\hline \multirow[t]{2}{*}{ Poz-26362 } & $3890 \pm 35$ & $2465-2340 \mathrm{BC}(68.2 \%)$ & $2250-2235 \mathrm{BC}(1.6 \%)$ \\
\hline & & $2475-2400$ BC (45.3\%) & $2550-2535$ BC (1.2\%) \\
\hline Poz-26979 & $3920 \pm 35$ & $2385-2345$ BC (22.9\%) & $2490-2290$ BC (94.2\%) \\
\hline
\end{tabular}

Table 1. Results of radiocarbon dating of charcoal. 


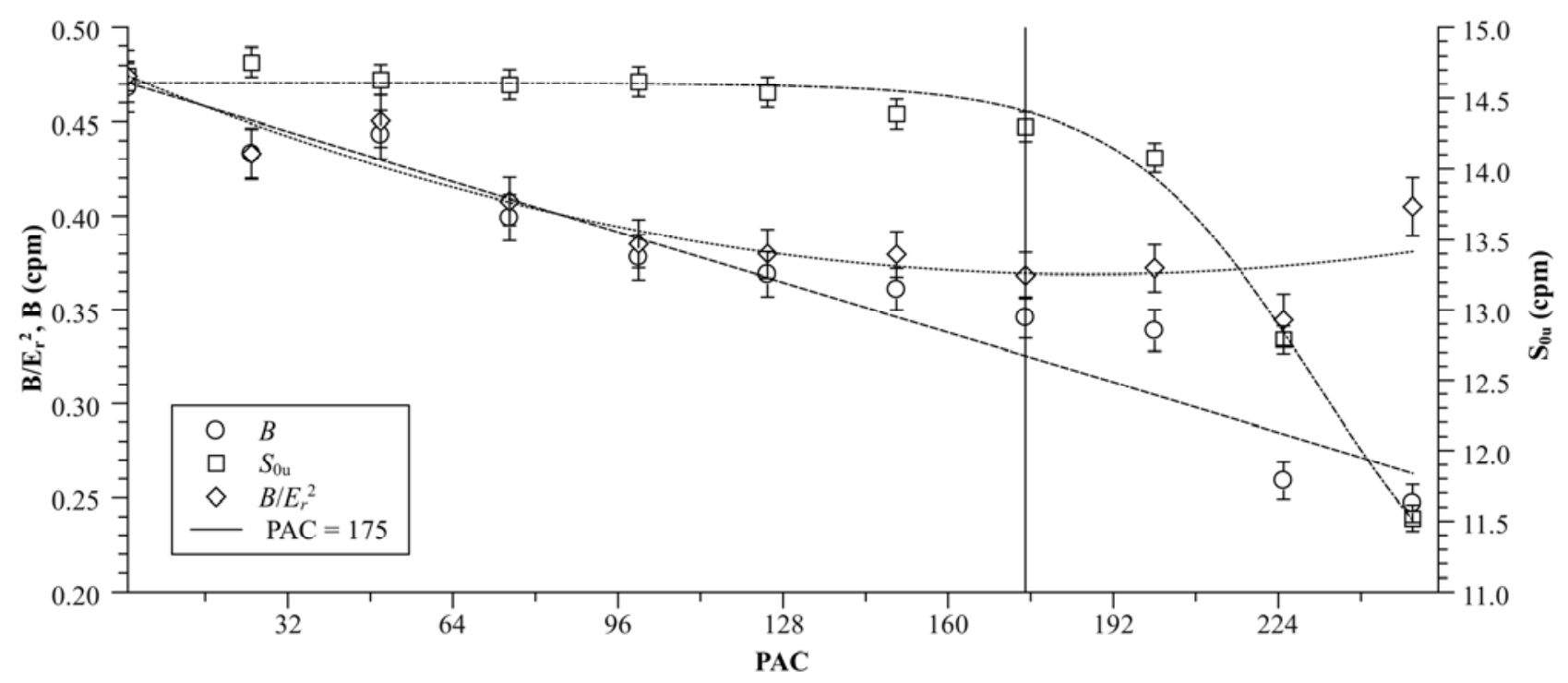

Fig. 2. $B, S_{0 u}$ and $B / E_{r}^{2}$ as $P A C$ function. The optimal $P A C$ value is 175 .

$S_{0}$ (PAC) modern standard counting rate as a function of $\mathrm{PAC}$. The $\mathrm{u}$ refers to values that are not corrected according to quenching effect. We set the PAC level for 175 (Fig. 2).

The factor of merit (FOM) is defined as:

$\operatorname{FOM}(L D, H D)=\frac{S_{0 \mathrm{u}}(L D, H D)}{\sqrt{B(L D, H D)}}$.

Routinely we use a fixed counting window (Fig. 4). The lower band of ${ }^{14} \mathrm{C}$ window is just above tritium spectrum to avoid its low energy beta radiation from the water used in benzene synthesis. The upper band is almost at the end of ${ }^{14} \mathrm{C}$ spectrum. The window that spans from channel 291 to 580 was chosen. It can be seen (Fig. 3) that the position of ${ }^{14} \mathrm{C}$ window, corresponds to almost

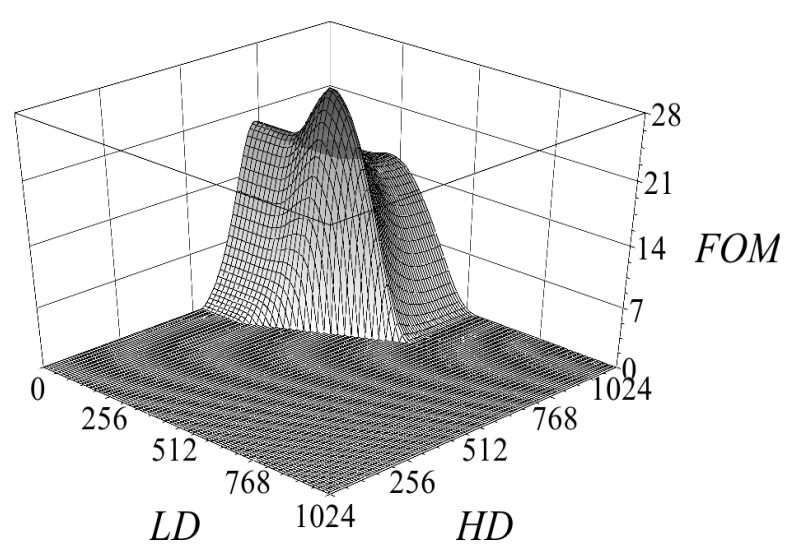

Fig. 3. FOM as a function of lower $(L D)$ and higher $(H D)$ band of ${ }^{14} \mathrm{C}$ window.

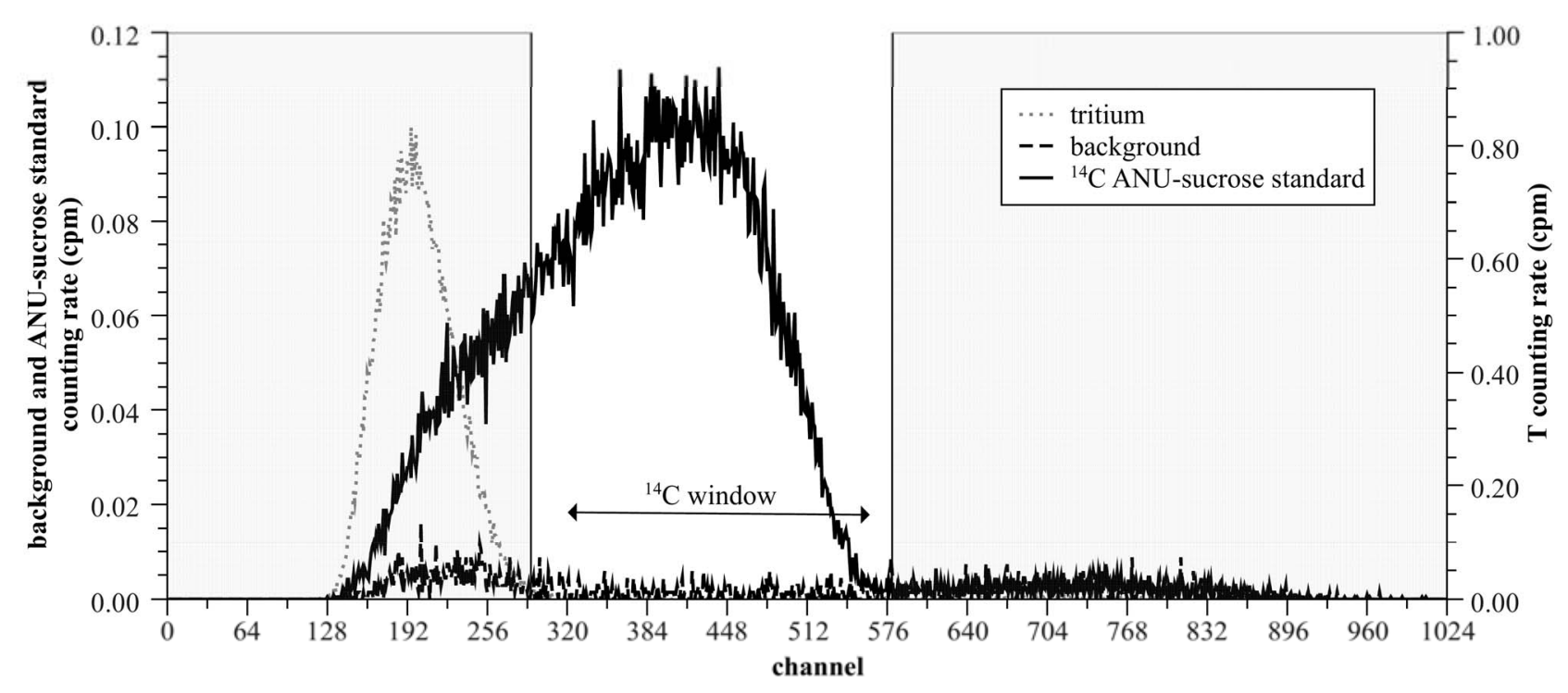

Fig. 4. Tritium, ${ }^{14} \mathrm{C}$ and background spectra with marked ${ }^{14} \mathrm{C}$ window. 


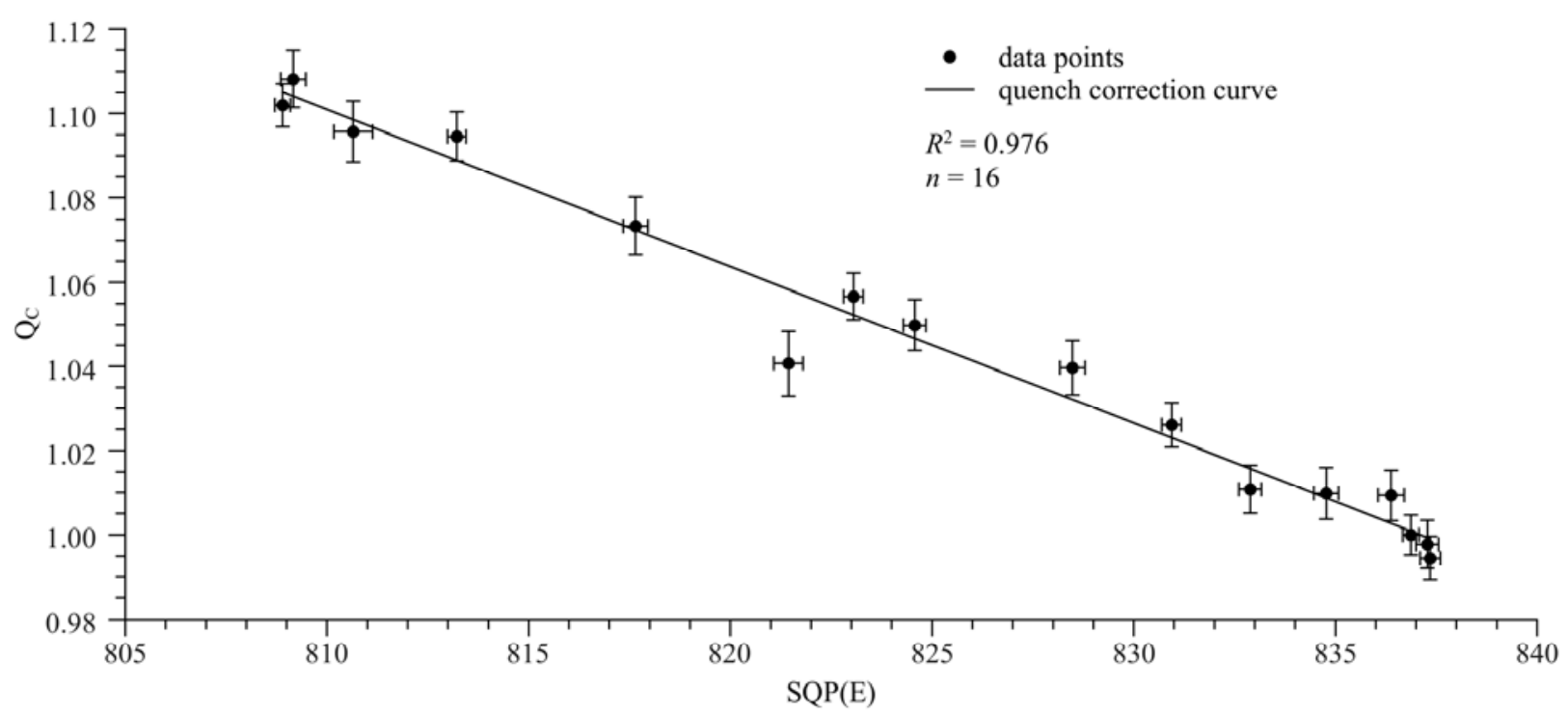

Fig. 5. Quench correction vs. quenching indicator $S Q P(E)$.

maximum of FOM surface. This will benefit when old or diluted samples are measured. In the next step we build up a quench correction curve $\left(Q_{c}\right)$ by quenching with acetone ANU-sucrose (Fig. 5). ANU-sucrose is a secondary standard proposed by Polach and Krueger (1972). The quench correction is defined as

$$
Q_{C}(\mathrm{SQP}(\mathrm{E}))=\frac{1}{E_{r}(\mathrm{SQP}(\mathrm{E}))},
$$

where $E_{r}(\mathrm{SQP}(\mathrm{E}))$ is relative efficiency as a function of $\mathrm{SQP}(\mathrm{E})$.

The explanation of spectral quench parameter of external standard (SQP(E)) of Quatulus $1220^{\mathrm{TM}}$ can be found for example in PerkinElmer ${ }^{\circledR}$ instrument manual (2005). Obtained SQP $(E)$ range (808-837) corresponds to the range of different purities of typical samples.
The Quantulus $1220^{\mathrm{TM}}$ is known for its stability and reproducibility. For ${ }^{14} \mathrm{C}$ data evaluation we use a wide range of activity standards and backgrounds. Fig. 6 shows result of the series of background measurements that were used and Fig. 7 shows counting rate of modern biosphere standards measurements.

The results presented in Figs. 6 and 7 prove that measurements carried out with use of new Quantulus $1220^{\mathrm{TM}}$ can be considered stable and reproducible. The basic parameters of Quantulus $1220^{\mathrm{TM}}$ are listed in Table 2.

In order to test the reliability of new Quantulus $1220^{\mathrm{TM}}$ we used available samples from International Radiocarbon Inter-comparison (VIRI, FIRI). Consensus VIRI values were reported by Scott in 2009 at the Radiocarbon Conference. The FIRI values were reported by Boaretto et al. (2002). The results are provided in Table 3.

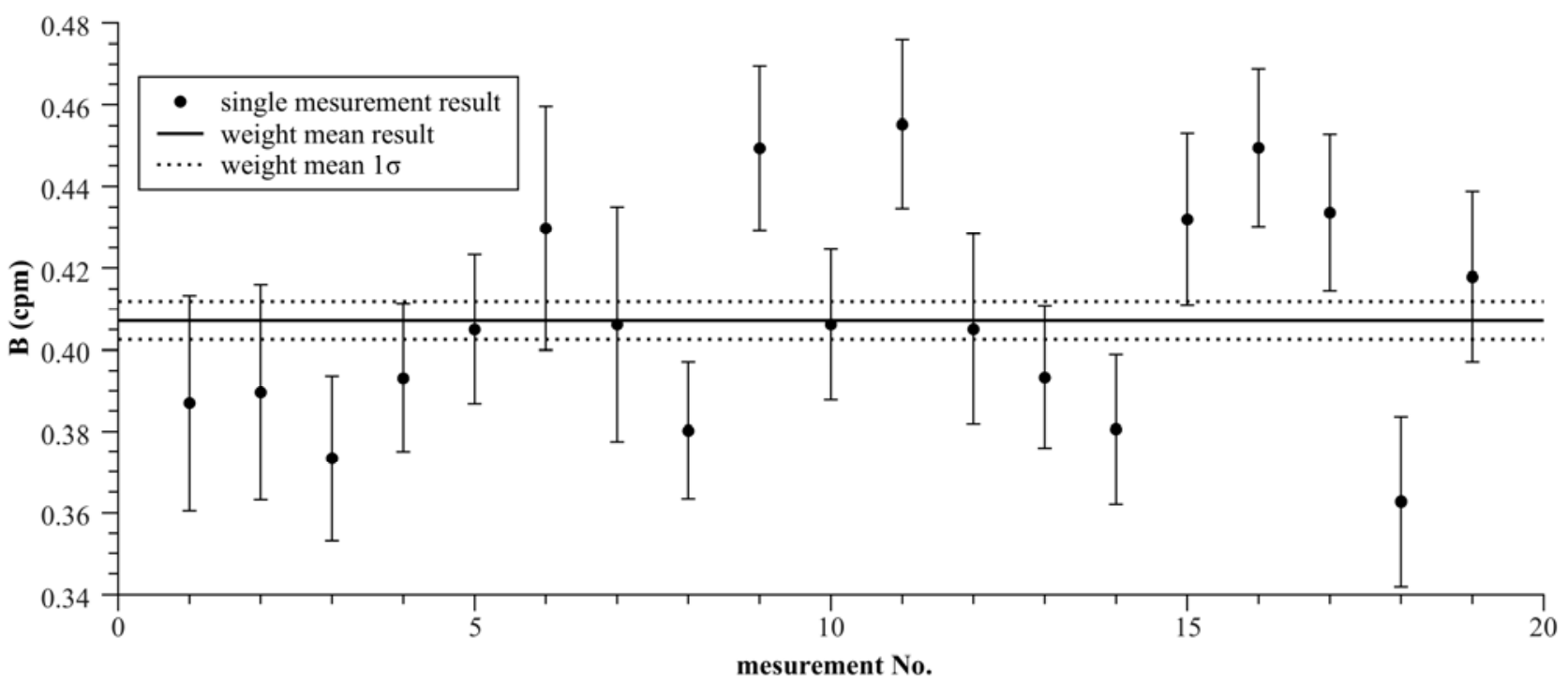

Fig. 6. Background counting rate stability and reproducibility with $1 \sigma$ uncertainty for single measurement. 2-3 day measurements spanned over 8 months. 


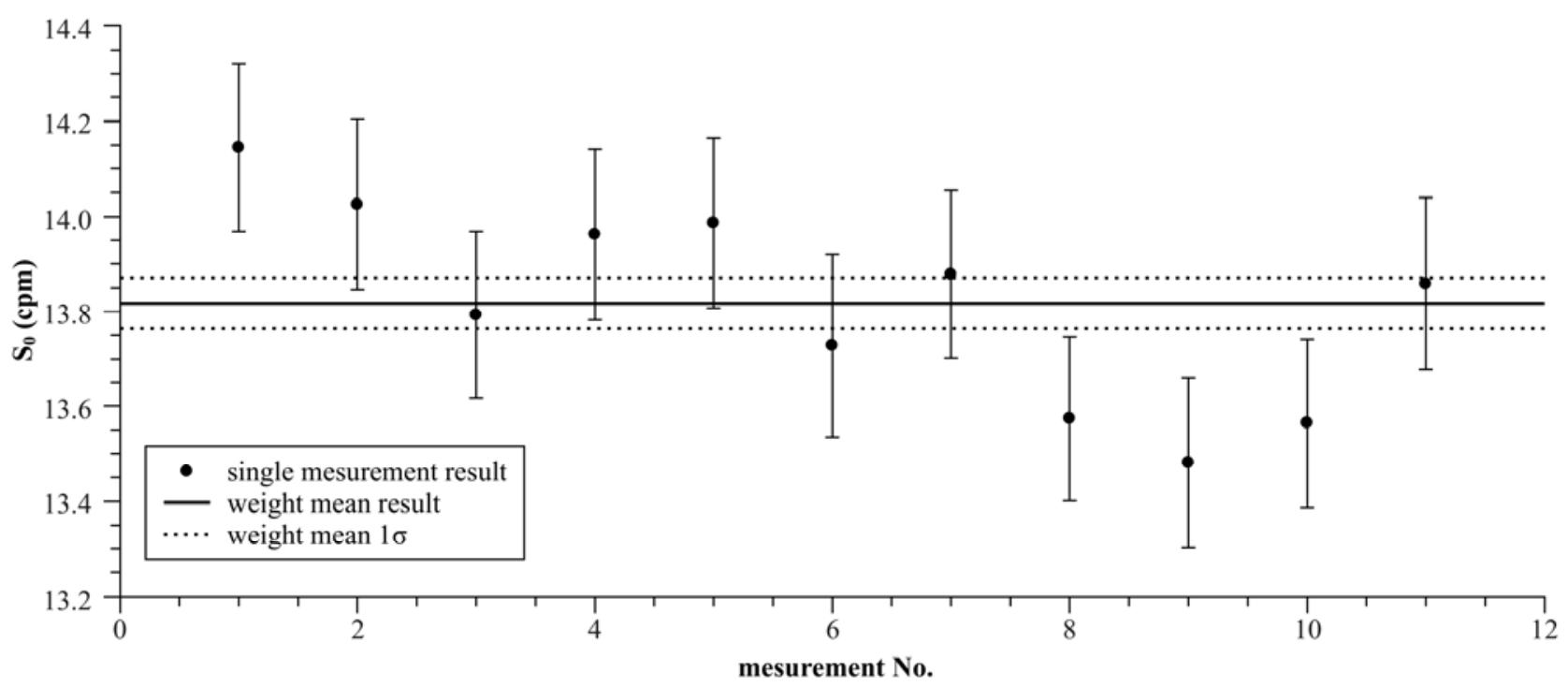

Fig. 7. Standard stability and reproducibility with $1 \sigma$ uncertainty for single measurement points. 2-3 day measurements spanned over 8 months.

\section{DATING RESULTS AND AGE-DEPTH MODEL}

A number of 17 peat samples were taken from Żyglin 3 core for conventional radiocarbon dating in Gliwice Radiocarbon Laboratory. The obtained dates were calibrated using OxCal v4.1.3 (Bronk Ramsey, 2009) and IntCal04 Northern Hemisphere calibration curve (Reimer et al., 2004). An age model was constructed from this data set on the basis on P_Sequence(0.1) (Bronk Ramsey, 2008). There were a lot of events that influenced this peat during last $14 \mathrm{kyr}$, taking into account that peat is very compressed (ca. $0.07 \mathrm{~mm} \cdot \mathrm{yr}^{-1}$ ), $k=0.1$ parameter is allowing for a number of changes. The similar peat agedepth model of a comparable time span was reported by Lamentowicz et al. (2009). Fig. 8 and Table 4 present the results of calibration and model.

\section{SUMMARY AND CONCLUSIONS}

The obtained age-depth model is characterised by good agreement of all the data points, as no inversions of dates were observed. Modelled distributions fit well to the model to a priori information and agreement parameter of model is $A_{\text {model }}=73 \%$. One of the samples, Żyglin 3/28-29 seems to be out of age-depth model (Fig. 8) but the agreement $(51.6 \%)$ is not low enough to determine if the sample is outlier. Much more precise and complex age-depth model is being developed.

Further investigations will include precise determination of time periods in which metals were smelted by

Table 2. Basic parameters of Quantulus $1220^{\mathrm{TM}}$

\begin{tabular}{ll}
\hline Geometry & $2 \mathrm{ml}$ \\
\hline$S_{0}(\mathrm{cpm})$ & $13.817 \pm 0.054$ \\
\hline$B(\mathrm{cpm})$ & $0.4072 \pm 0.0047$ \\
\hline FOM $\left(\mathrm{cpm}^{0.5}\right)$ & 21.7 \\
\hline$T_{\max }{ }^{*}(\mathrm{BP})$ & 44100 \\
\hline
\end{tabular}

${ }^{*}$ - for 1000 min measuring time means of radiocarbon and chemical investigations. It can be done by seeking for presence of those particular metals in dated peat levels. The origin of metals would be a very valuable information and in some cases it can be obtained by analyses of lead isotopes $\left({ }^{204} \mathrm{~Pb},{ }^{206} \mathrm{~Pb},{ }^{207} \mathrm{~Pb},{ }^{208} \mathrm{~Pb}\right)$ ratios. The measurements are currently in progress in frame of the cooperation between Silesian University of Technology (Poland) and University of Liege (Belgium).

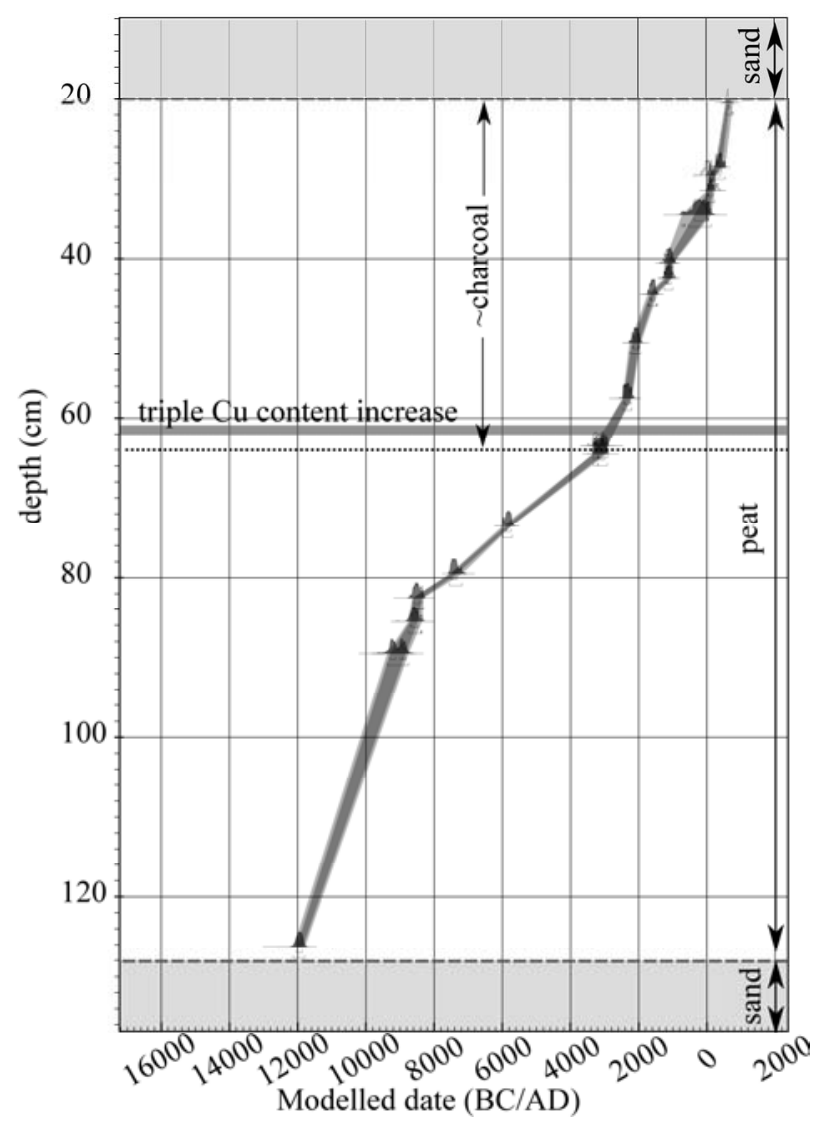

Fig. 8. Age depth model of investigated profile with approximately marked levels of $\mathrm{Cu}$ increase and section of high charcoal content. 
Table 3. Quantulus $1220^{\mathrm{TM}}$ calibration verification with results from inter-comparison programs.

\begin{tabular}{lccccc}
\hline & & \multicolumn{2}{c}{ Quantulus 1220 $^{\text {TM }}$} & \multicolumn{2}{c}{ Consensus values } \\
\cline { 3 - 6 } Sample name & Unit & Value & $\mathbf{1 \sigma}$ & Value & $\mathbf{1 \sigma}$ \\
\hline VIRI B & $(\mathrm{BP})$ & 2825 & 65 & 2820 & 4 \\
VIRI C & $(\mathrm{pMC})$ & 107.15 & 0.58 & 110.7 & 0.04 \\
VIRI D & $(\mathrm{BP})$ & 2895 & 65 & 2836 & 4 \\
FIRI C & $(\mathrm{BP})$ & 17740 & 190 & 18176 & 10.5 \\
FIRI F & $(\mathrm{BP})$ & 4495 & 115 & 4508 & 3 \\
FIRI I & $(\mathrm{BP})$ & 4200 & 160 & 4485 & 3 \\
FIRI J & (pMC) & 108.33 & 1.5 & 110.7 & 0.04 \\
\hline
\end{tabular}

Table 4. Conventional radiocarbon age and modelled age range.

\begin{tabular}{|c|c|c|c|c|c|}
\hline Sample name & $\begin{array}{l}\text { Depth } \\
(\mathrm{cm})\end{array}$ & $\begin{array}{c}\text { Conventional } \\
\text { age (BP) }\end{array}$ & $\begin{array}{c}\text { Modelled age range } \\
68.2 \% \\
\end{array}$ & $\begin{array}{c}\text { Modelled age range } \\
95.4 \% \\
\end{array}$ & $\begin{array}{c}\text { Agreement } \\
(\%)\end{array}$ \\
\hline Żyglin 3/125-127.5 cm & $125-127.5$ & $12040 \pm 80$ & $12035-11850 \mathrm{BC}(68.2 \%)$ & $12165-11775 \mathrm{BC}(95.4 \%)$ & 99.5 \\
\hline Żyglin 3/89-90 cm & $89-90$ & $9740 \pm 110$ & $\begin{array}{l}9290-9130 \mathrm{BC}(33.5 \%) \\
9005-8835 \mathrm{BC}(34.8 \%)\end{array}$ & $9375-8750 \mathrm{BC}(95.4 \%)$ & 91.2 \\
\hline Żyglin 3/85-86 cm & $85-86$ & $9320 \pm 80$ & $\begin{array}{c}8695-8680 \mathrm{BC}(3.4 \%) \\
8650-8475 \mathrm{BC}(64.8 \%)\end{array}$ & $8755-8350$ BC (95.4\%) & 109.7 \\
\hline Żyglin 3/82-83 cm & $82-83$ & $9265 \pm 70$ & $\begin{array}{l}8615-8435 \text { BC }(66.9 \%) \\
8365-8355 \text { BC }(1.3 \%)\end{array}$ & $8640-8305$ BC (95.4\%) & 104.9 \\
\hline Żyglin 3/79-80 cm & $79-80$ & $8340 \pm 75$ & $7515-7330 \mathrm{BC}(68.2 \%)$ & $7545-7180 \mathrm{BC}(95.4 \%)$ & 100.9 \\
\hline Żyglin 3/73-74 cm & $73-74$ & $6945 \pm 70$ & $5895-5745 \mathrm{BC}(68.2 \%)$ & $5985-5715$ BC (95.4\%) & 99.8 \\
\hline Żyglin 3/64-65 cm & $64-65$ & $4435 \pm 65$ & $\begin{array}{c}330-3220 \text { BC }(28.2 \%) \\
3180-3160 \text { BC }(3.4 \%) \\
3120-3010 \text { BC }(35.2 \%) \\
2980-2970 \text { BC }(1.4 \%)\end{array}$ & $\begin{array}{l}3340-3205 \mathrm{BC}(32.3 \%) \\
3195-2925 \mathrm{BC}(63.1 \%)\end{array}$ & 102.9 \\
\hline Żyglin 3/63-64 cm & $63-64$ & $4445 \pm 90$ & $\begin{array}{c}3310-3295 \mathrm{BC}(2.2 \%) \\
3285-3230 \mathrm{BC}(10.9 \%) \\
3170-3160 \mathrm{BC}(1.0 \%) \\
3120-2925 \mathrm{BC}(54.0 \%)\end{array}$ & $\begin{array}{l}3330-3205 \text { BC }(25.7 \%) \\
3195-2915 \text { BC }(69.7 \%)\end{array}$ & 105.1 \\
\hline Żyglin 3/57-58 cm & $57-58$ & $3865 \pm 50$ & $\begin{array}{c}2455-2415 \text { BC }(13.7 \%) \\
2410-2285 \text { BC }(51.6 \%) \\
2250-2235 \text { BC }(2.9 \%)\end{array}$ & $2470-2195 \mathrm{BC}(95.4 \%)$ & 990 \\
\hline Żyglin 3/50-51 cm & $50-51$ & $3695 \pm 50$ & $\begin{array}{c}2195-2175 \text { BC }(6.8 \%) \\
2145-2020 \text { BC }(59.3 \%) \\
1995-1980 \text { BC }(2.1 \%)\end{array}$ & $\begin{array}{c}2275-2255 \text { BC }(1.3 \%) \\
2210-1935 \text { BC (94.1\%) }\end{array}$ & 91.5 \\
\hline Żyglin 3/44-45 cm & $44-45$ & $3315 \pm 55$ & $\begin{array}{c}1665-1650 \text { BC }(5.0 \%) \\
1645-1520 \text { BC }(63.2 \%)\end{array}$ & $\begin{array}{c}1740-1705 \text { BC }(4.3 \%) \\
1700-1490 \text { BC (89.1\%) } \\
1480-1455 \text { BC }(2.0 \%)\end{array}$ & 99.8 \\
\hline Żyglin 3/42-43 cm & $42-43$ & $2910 \pm 50$ & $\begin{array}{l}1210-1140 \mathrm{BC}(27.4 \%) \\
1135-1050 \mathrm{BC}(40.8 \%)\end{array}$ & $1265-1010$ BC (95.4\%) & 104.9 \\
\hline Żyglin 3/40-41 cm & $40-41$ & $2915 \pm 55$ & $\begin{array}{l}1190-1175 \text { BC }(3.4 \%) \\
1165-1140 \text { BC }(7.1 \%) \\
1135-1020 \text { BC }(57.7 \%)\end{array}$ & $\begin{array}{l}1260-1225 \text { BC (3.3\%) } \\
1220-975 \text { BC (92.1\%) }\end{array}$ & 111.3 \\
\hline Żyglin 3/34-35 cm & $34-35$ & $2205 \pm 145$ & $\begin{array}{c}370-40 \mathrm{BC}(59.7 \%) \\
15 \mathrm{BC}-5 \mathrm{AD}(2.8 \%) \\
10-25 \mathrm{AD}(2.2 \%) \\
40-65 \mathrm{AD}(3.5 \%)\end{array}$ & $\begin{array}{c}735-690 \text { BC }(1.4 \%) \\
665-650 \text { BC }(0.3 \%) \\
550 B C-135 \text { AD }(93.7 \%)\end{array}$ & 91.1 \\
\hline Żyglin 3/31-32 cm & $31-32$ & $1830 \pm 55$ & $\begin{array}{c}30-40 \mathrm{AD}(2.0 \%) \\
50-145 \mathrm{AD}(60.8 \%) \\
155-170 \mathrm{AD}(3.6 \%) \\
195-205 \mathrm{AD}(1.8 \%)\end{array}$ & $10-235 \mathrm{AD}(95.4 \%)$ & 76.9 \\
\hline Żyglin 3/29-30 cm & $29-30$ & $1990 \pm 65$ & $\begin{array}{c}55-140 \mathrm{AD}(53.0 \%) \\
160-170 \mathrm{AD}(2.7 \%) \\
185-220 \mathrm{AD}(12.5 \%)\end{array}$ & $15-240$ AD (95.4\%) & 51.6 \\
\hline Żyglin 3/28-29 cm & $28-29$ & $1660 \pm 50$ & $\begin{array}{l}255-290 \mathrm{AD}(13.5 \%) \\
325-435 \mathrm{AD}(54.7 \%)\end{array}$ & $240-535$ AD (95.4\%) & 95.3 \\
\hline Żyglin $3 / 20-21 \mathrm{~cm}$ & $20-21$ & $1410 \pm 55$ & $585-665$ AD (68.2\%) & $\begin{array}{l}535-715 \text { AD (93.8\%) } \\
745-770 \text { AD (1.6\%) }\end{array}$ & 98.9 \\
\hline
\end{tabular}


Due to the conditions and sand covering the fen the peat has not decomposed for over $14 \mathrm{kyr}$ which gives a perfect opportunity to investigate early human activity and climate changes in Silesia region. On the other hand, the high compaction is main difficulty, and great care is need while bonding events to the time scale.

\section{ACKNOWLEDGEMENTS}

We are grateful to Leszek Chróst from Laboratory for Ecological Research, Measurement and Expertise "EKOPOMIAR" for inviting us to these researches and sharing his large experience.

The authors would like to thank to Jacek Pawlyta for valuable discussion about calibration of Quantulus $1220^{\mathrm{TM}}$.

\section{REFERENCES}

Ali AA, Ghaleb B, Garneau M, Asnong H and Loisel J, 2008. Recent peat accumulation rates in minerotrophic peatlands of the Bay James region, Eastern Canada, inferred by ${ }^{210} \mathrm{~Pb}$ and ${ }^{137} \mathrm{Cs}$ radiometric techniques. Applied Radiation and Isotopes 66 (10) 13501358, DOI 10.1016/j.apradiso.2008.02.091.

Bellwood PS, 2004. First Farmers: The Origins of Agricultural Societies. Padstow, Blackwell Publishers: 384pp.

Boaretto E, Bryant C, Carmi I, Cook G, Gulliksen S, Harkness D, Heinemeier J, McClure J, McGee E, Naysmith P, Possnert G, Scott M, van der Plicht $H$ and van Strydonck M, 2002. Summary findings of the fourth international radiocarbon intercomparison (FIRI)(1998-2001) Journal of Quaternary Science 17(7): 633-637, DOI: $10.1002 /$ jqs. 702 .

Bronk Ramsey C, 2008. Deposition models for chronological records. Quaternary Science Reviews 27(1-2): 42-60, DOI 10.1016/j.quascirev.2007.01.019.

Bronk Ramsey C, 2009. Bayesian analysis of radiocarbon dates. Radiocarbon 51(1): 337-360.

Cavalli-Sforza LL, Menozzi P, Piazza A, 1994. The History and Geography of Human Genes. New Jersey, Princeton University Press: 1088 pp.

Chróst L, Kandzia M and Wasielewski R, 2007. Sprawozdanie końcowe z wykonania zadania publicznego "Określenia intensywności dawnej produkcji srebra i ołowiu w rejonie Tarnowskich Gór w oparciu o pomiary depozycji ołowiu w torfowiskach" (Final report on the Estimation of the intesity of the early Silver and Lead production in the region of Tarnowskie Góry, Poland, based on the deposition of Lead recorded in peat bogs). Project on Public Procurement. Wydział Kultury Urzędu Marszałkowskiego Woj. Śląskiego (Katowice, Poland) i Stowarzyszenie Miłośników Ziemi Tarnogórskiej (Tarnowskie Góry, Poland): 52pp (in Polish).

Chróst L, Kandzia M and Wasielewski R, 2008. Sprawozdanie końcowe z wykonania zadania publicznego „Określenie usytuowania w rejonie Tarnowskich Gór ośrodków wczesnośredniowiecznego hutnictwa ołowiu i srebra metodą pomiarów lokalnego skażenia torfowisk i gleb ołowiem" (Final report on the Localization of the early medieval Silver-Lead smelting centers in the area of Tarnowskie Gory, Poland, based on the determination of the Lead contamination of soil and peat. Project on Public Procurement.) Wydział Kultury Urzędu Marszałkowskiego Woj. Śląskiego (Katowice, Poland) i Stowarzyszenie Miłośników Ziemi Tarnogórskiej (Tarnowskie Góry, Poland): 38pp (in Polish).

Cook GT, Dugmore AJ, Shore JS, 1998. The influence of pretreatment on humic acid yield and ${ }^{14} \mathrm{C}$ age of carex peat. Radiocarbon $40(1)$ : 21-27.

Godfrey-Smith DI Casey JL, 2003. Direct thermoluminescence chronology for Early Iron Age smelting technology on the Gambaga Escarpment, Ghana. Journal of Archaeological Science 30:10371050, DOI 10.1016/S0305-4403(02)00292-3.

Greger J and Składowski M, 2009. Determination of Copper in acidic peat extracts from the selected layers of the Żyglin peat bog profile acquired in 2008. Report from Ośrodek Badań i Kontroli Środowiska (Katowice, Poland) 1pp (in Polish).

Lamentowicz M, Balwierz Z, Forysiak J, Płóciennik M, Kittel P, Kloss M, Twardy J, Żurek S and Pawlyta J, 2009. Multiproxy study of anthropogenic and climatic changes in the last two millennia from a small mire in central Poland. Hydrobiologia 631: 213-230, DOI 10.1007/s10750-009-9812-y.

Pawlyta J, Pazdur A, Rakowski A, Miller B F and Harkness D D, 1998. Commissioning of Quantulus $1220^{\mathrm{TM}}$ liquid scintillation beta spectrometer for measuring ${ }^{14} \mathrm{C}$ and ${ }^{3} \mathrm{H}$ at natural abundance levels. Radiocarbon 40(1): 201-209.

PerkinElmer $^{\circledR}, 2005$. Wallac 1220 Quantulus ${ }^{\mathrm{TM}}$ Ultra Low Level Liquid Scintillation Spectrometer. Instrument manual, 1220-931-08.

Polach, HA and Krueger, HA, 1972. Isotopic fractionation of NBS oxalic acid and ANU-sucrose radiocarbon dating standards: international conference on radiocarbon dating, 8th, Wellington, New Zealand, Proc, p 718-724.

Rapp GR, 2009. Archaeomineralogy. Berlin, Springer: 348pp, DOI 10.1007/978-3-540-78594-1.

Reimer PJ, Baillie MGL, Bard E, Bayliss A, Beck JW, Bertrand C, Blackwell PG, Buck CE, Burr G, Cutler KB, Damon PE, Edwards RL, Fairbanks RG, Friedrich M, Guilderson TP, Hughen KA, Kromer B, McCormac FG, Manning S, Bronk Ramsey C, Reimer RW, Remmele S, Southon JR, Stuiver M, Talamo S, Taylor FW, van der Plicht J, and Weyhenmeyer CE. 2004. IntCal04 terrestrial radiocarbon age calibration, 0-26 cal kyr BP. Radiocarbon 46(3): 1029-1058.

Scott M, 2009. A first summary of the consensus values for all the VIRI samples. Results were reported at the Radiocarbon conference in Hawaii (detailed report is being prepared for publication. Consensus values available at WEB site: <http://www.radiocarbon.org/>. Accessed 2009 November 11.

Stuiver M, Polach HA 1977. Discussion reporting of C-14 data. Radiocarbon 19(3): 355-363.

Vile1 MA, Kelman Wieder R and Novák M, 1999. Mobility of Pb in Sphagnum-derived peat. Biogeochemistry 45: 35-52, DOI 10.1023/A:1006085410886. 